С. Абросимова, Н. Василенко, А. Перкова; За заг. ред. Н. Капустіної. Дніпропетровськ : АРТ-ПРЕС, 2005. 500 с.

2. Кримський А. Ю. Твори : В 5-ти т. Київ : Наук. думка, 1972-1974. Т. 3 : Мовознавство. Фольклористика. 508 с.

3. Рильський М. Запорозький характерник / М. Чабан. Сучасники про Д. І. Яворницького : Спогади. Дніпропетровськ: ВПОП Дніпро, 1995. С. $72-75$.

4. Яворницький Д. I. За чужий гріх: Роман, повість, малюнки 3 життя. Дніпропетровськ : Січ, 2006. 600 с.

DOI https://doi.org/10.30525/978-9934-26-073-5-1-6

\title{
МАКСИМА ЩАСТЯ В МОВНО-СВІТОГЛЯДОВОМУ ПРОСТОРІ ДМИТРА ДОНЦОВА
}

\author{
Микитюк О. P. \\ кандидат філологічних наук, \\ доцент катедри української мови \\ Національного університету «Львівська політехніка» \\ м. Львів, Україна
}

Ціннісним $є$ вивчення мови крізь призму атропоцентризму, бо мовна особистість $є$ базою для розуміння певного суспільно-політичного та культурно-історичного періоду. Особливої уваги заслуговує прочитання публіцистичних творів Д. Донцова, які відтворюють менталітет українців, оприявнюють індивідуальний стиль автора, відображають характерні ознаки мовної картини світу. Серед глибинних покладів Донцової мови неординарною $є$ максима щзастя, яка невіддільно пов'язана 3 усвідомленням тожсамости, неповторности та поступу. Відтак завданням роботи є: 1) з'ясувати розуміння щастя за творами Д. Донцова, 2) охарактеризувати національну специфіку аналізованого слова, 3) подати сутнісні ознаки максими щзастя за мислителем.

Визначення лексеми щъастя дуже різноманітне, зазвичай має позитивну конотацію та передбачає суцільно позитивні семи, наприклад, 'радість', 'задоволення', 'симпатія', 'любов', 'успіх', 'удача', 'доля', 'талан', ‘добробут'. Відмінним від такої характеристики є смислове наповнення слова щастя в Д. Донцова, що уможливило активізацію концептуально інших сем, яких не відтворюють лексикографічні праці. 
Мовно-мисленнєвий аналіз творів Д. Донцова дозволяє стверджувати, що максима щастя вміщує в собі світоглядові, політико-культурні, націє- та державоцентричні аспекти, зокрема, потребу бути сильним, вміти боротися, бути діяльним, формувати власну українську позицію. Себто визначення щзастя в Д. Донцова має фундаментально відмінні від загальновизнаних пріоритети та засади, а в когнітивістиці «генератором значень висловлювань $€$ людина як носій когніції, яка обирає власний або нав'язаний ій мовою спосіб інтерпретації дійсності» [4, с. 240].

Метафоричне мислення письменника, розсипи ідей та емоційні судження створюють розмаїтість дефініцій лексеми щзастя та формують сентенційно-фразеологічне поле. Відтак маємо неповторні твердженняафоризми: «Щастя - ие бути сильним» [2, с. 136], «Не в здобутті $\epsilon$ щастя, а в здобуванні» [3, с. 158], «Щастя - се скажений рвучкий потік, щцо в хвилини повені затоплює все довкола» [1, т. 2, с. 214]. На противагу Д. Донцову, СУМ визначає щастя як «стан цілковитого задоволення життям» [5, т 11, с. 573], що не зіставно з боротьбою, силою, потугою, величчю в Д. Донцова. Варто звернути увагу, що всеохопність поняття щастя висвітлено окремим розділом у збірці афоризмів публіциста [7, с. 83], мета якої утверджувати націєцентричні ідеали.

Д. Донцов постійно торкається сутнісних ознак максими щастя, оскільки він категорично проти щастя в спокої, а розуміє щастя як чин, як рух, таким чином семи цього слова сповна відповідають мисленнєвій специфіці автора, який силою слова завжди змінював суспільну свідомість. Український літературний критик не лише продукує однозначні твердження щодо лексеми щзастя, а й підкріплює свою позицію думками відомих діячів, Наприклад, він цитує англійського філософа Т. Гобса, у якого щзастя - це «безперервний поступ і розвій бажання від одного об'єкту до другого, здобуття одного предмету, за поміччю якого ідеться до здобуття другого»»» [3, с. 158]. Також метафорично пояснює великий публіцист максиму щзастя за французьким письменником Г. Валуа («Людина, що приходить»), бо «обличчя насолоди» під звабливими фарбами ховає кістяк, а «те, що нам видається щастям, є ферментом розкладу для громади, до якої належимо» [1, т. 2, с. 234]. У висліді Д. Донцов показує, що закони життя та щастя вимагають постійної праці, а будь-яка зупинка в житті призводить до загибелі.

Особливо неповторним $є$ тематичний вектор розуміння щастя в різних народів, що стверджує ідею національного характеру максими щастя. Наприклад, щзастя в Т. Шевченка - це щастя свого народу. Д. Донцов серед текстів Кобзаря виокремлює ті смисли, які формували позицію та виховували характер. Отож він спостеріг, що щастя для 
національного Пророка - це той час, коли Україну боялися вороги, коли козаки вміли відбити ворожі удари, тобто, коли «запорожці вміли панувати», тому «було колись добре жити на тій Україні» [2, с. 124]. Тотожний приклад мислитель наводить щодо князя Святослава, для якого щастя - це напруження, боротьба, величні дії в обороні своєї землі. Важливо, що етимологізація лексеми щзастя стосується «спільної участи» [6, с. 816], відтак значення слова показує належність до частини, яка немислима без національної єдности (що потверджує думку Д. Донцова про національну специфіку щастя).

Прикметно, що щастя української жінки Д. Донцов визначає не лише як берегині родинного огнища, а жінка (у нього це О. Теліга), що надважливо, стоїть «на сторожі цілости, щастя і могутности більшої родини - нації» [1, т. 8, с. 212].

Аналогічним до українського щастя (зі семами 'сила', 'здобування', 'рвучкість') є щастя європейця, яке визначено за мислителем як боротьба, а не насолода. Свропеєць гордить особистим життям i добробутом, тому основними атрибутами щастя є завзяття, енергія, відвага, але не спокій. Ще один приклад, який вимальовує Д. Донцов 3 максимою щзастя, стосується американця, для якого щастя - це постійна гонитва за чимось більшим, за тим, що дає насолоду, але коли американець схоплює уявне щастя, то він його «не затримує довго, лиш випускає з рук зараз, щоб бігти за новими радощами $<\ldots,>$, і лише смерть спиняє сю гонитву за щастям, що все від нього тікає!» [1, т. 2, с. 276].

Отже, ментально сильні українці (передусім уславлено величні князівські та козацькі часи), європейці (їхьою ознакою щастя $\epsilon$ запеклість та неспокій), американці (для яких важливий своєрідний дух гонитви) - усі вбачають щастя в русі, у невпинному розвиткові. Цілковито протилежним до такого розуміння щастя $\epsilon$ щастя провансальців, яких нещадно та викривально висміює публіцист, бо ідеал провансальця - це «спокій і щастя в спокою; непорушність, тиха погідність, стояча вода» [3, с. 119]. Саме оцю незворушність Д. Донцов буде показувати в низки письменників, які обрали пасивно-споглядальну позицію, пропагували спокійне життя, а це знищувало відпорну силу українців, призводило до пристосуванства, нищило національний характер. Відтак ідеї М. Драгоманова («вселюдське щастя», «українець просить немного»), П. Куліша (зі щастям на власному хуторі) та ін. призвели до атрофії української психіки, що відбулася під впливом московської «ідеологієї милосердя», яку спропагував М. Горький такою позицією: «Нам потрібні лікарі, а не судді, не прокурори, а утішителі світу» [1, т. 2, с. 110]. Цю занепадницьку для психіки політику Д. Донцов викриває в творі «Культура примітивізму». 
Вкрай негативно мислитель ставиться до слабкости, яку пропонує естетика декадансу. Усіх слабких об'єднує таким синонімним рядом: втомлені, змучені, «зрозпачені», заплакані, духові каліки, істерики, стужені за «щастям пасічника», духові ледарі, нудярі - усі, що забрали 3 житті (і зі щастя ) твердість силу та волю й створили естетику декадансу, що «обезвартнює життя, вчить резигнації і позбавляє сили опору, що вбиває жадобу» [1, т. 8, с. 146]. Тому мислитель силою свого авторитету пропонує діяльність, яка увиразнює життя та надає йому сенсу.

Реконструкція мовної свідомости Д. Донцова відтворює історикополітичний час та виводить на поверхню його життєві пріоритети: виховувати нове покоління, обстоювати духові прагнення, творити Українську державу. Семантично прозорим $\epsilon$ етнокультурне підгрунтя максими щзастя в Д. Донцова, базоване на традиційних цінностях. Він, мислитель-енциклопедист, що володів українською, німецькою, французькою, польською, російською, італійською мовами, знавець української та европейської класичної літератури, блискучий аналітик та гострий публіцист, який для визначення такого, на перший погляд, позитивного явища як щзастя, виводить власну формулу, що підкріплює важливість національних пріоритетів та дає усвідомлення власної ролі у світі.

Д. Донцов крізь призму аналізованої максими якнайточніше подав ідеологічні настанови та національні виміри української політики й створив власний мовно-світоглядовий простір для розуміння екзистенційної категорії щзастя.

\section{Література:}

1. Донцов Д. Вибрані твори: в 10 т. / Упоряд., передм., комент. О. Баган. Т. 1-10. Дрогобич: Відродження, 2011-2016.

2. Донцов Д. Дух нашої давнини. Львів-Київ: Накладом Юрія Криворучка, 2011. 160 с

3. Донцов Д. Націоналізм. Вінниця: ДП «ДКФ», 2006. 236 с.

4. Селіванова О. О. Лінгвістична енциклопедія. Полтава: Довкілля. 2011. $844 \mathrm{c}$.

5. Словник української мови: в 11 т. / ред. колег. І. К. Білодід (голова) та ін. Київ: Наукова думка, 1979. Т. 11.700 с.

6. Фасмер М. Этимологический словарь русского языка. Т. 3. Москва: Прогресс, 1971.828 с.

7. Щастя - бути сильним. Афоризми та сентенції Дмитра Донцова / Автор ідеї та укладач Оксана Микитюк. Науковий консультант - Ірина Фаріон. Львів: Видавництво Львівської політехніки, 2021. 392 с. 